\title{
New data on the spiders (Arachnida: Aranei) from Altai Territory, Russia
}

\author{
Новые данные о пауках (Arachnida: Aranei) \\ Алтайского края, Россия
}

\begin{abstract}
Alexander A. Fomichev
А.А. Фомичев

Altai State University, Lenina Prospect, 61, Barnaul, 656049, Russia. E-mail: a.fomichov@mail.ru Алтайский Государственный Университет, Проспект Ленина, 61, Барнаул, 656049, Россия.

KEY WORDS: Tigirek State Nature Reserve, the Altai, Spiders, Aranei, new species, fauna, new records.

КЛЮЧЕВЫЕ СЛОВА: Тигирекский заповедник, Алтай, Пауки, Aranei, новый вид, фауна, новые находки.
\end{abstract}

ABSTRACT: A list of 65 spider species collected from the Tigirek State Nature Reserve (Altai Territory) is provided. Of them, 22 species are recorded from the reserve for the first time and six species are new to the Altai Mountains. A new species, Parasyrisca volynkini sp.n. $\left(\mathrm{O}^{7}\right)$ is described. Two species are illustrated: the poorly-illustrated female of Leptorhoptrum robustum (Westring, 1851) and Euryopis laeta (Westring, 1861) that is new to the Altai.

РЕЗЮМЕ: Приводится список 65 видов пауков собранных в Тигирекском заповеднике. Из них, 22 вида приводятся для заповедника впервые, а шесть впервые отмечаются для Алтайских гор. Описан новый вид Parasyrisca volynkini sp.n. $\left(\mathrm{O}^{7}\right)$. Проиллюстрированы ранее плохо иллюстрированная самка Leptorhoptrum robustum (Westring, 1851) и новый для Алтая вид Euryopis laeta (Westring, 1861).

\section{Introduction}

Altai Territory (= Altaisky Krai) is a region of Russia situated in the south-eastern part of West Siberia. This territory belongs to two physiographical areas: West Siberian Plain (in its western, northern and central parts) and Altai-Sayan Mountain Region represented by the Altai Mts and Salair Mt. Ridge (in its southern and eastern parts). The araneofauna of Altai Territory and the neighboring Altai Republic consists of about 600 species [Azarkina, Trilikauskas, 2013b] and is yet studied inadequately.

The present paper is devoted to one of the poorlystudied Altai regions, the Tigirek State Nature Reserve, situated in the western sector of the Tigirek Mt. Range. The reserve was founded in the south-western part of Altai Territory in 1999, aiming at conservation of the biodiversity of the West Altai [Davydov et al., 2011], the territory that lies in the westernmost limit of the mountains of South Siberia and is known to be one of the most humid regions of the entire northern Asia. A high precipitation combined with high insulation determines a development of regional communities containing nemoral elements both in the flora and in the fauna [Lukhtanov, 2007].

First sporadic data about spiders of the Tigirek State Nature Reserve were published in several taxonomical papers [Azarkina, Logunov, 2000; Logunov, Marusik, 2000; Marusik et al., 2004]. Special studies of the spider fauna of the reserve started not long ago. The first annotated checklist of spiders of the Tigirek Reserve was compiled by L.A. Trilikauskas to include 132 species (except for unidentified ones) [Volynkin et al., 2011]. Later, some data about this spider fauna appeared in a series of the papers by Azarkina \& Trilikauskas [2012, 2013a,b], in [Trilikauskas, 2014] and the number of species has increased to 153 . Nevertheless, the spider fauna of the Tigirek Nature Reserve remains studied incompletely. Several short collecting trips undertaken by the author and his collaborators to the reserve in 2011, 2012 have revealed 22 species that are new to the reserve, of which six are new to the Altai Mts and one is new to science. The aims of this paper are to provide a list of all the recorded spider species from the Tigirek Reserve, to comment on new faunistic records and to describe a new species.

\section{Material and methods}

This paper is based on the spider material collected by the author in July and August 2014, by A.V. Volynkin in July 2010, 2012 and by Yu.V. Dyachkov in August 2014. The material was collected in several localities situated in the western part of the Tigirek Mt. Range and in its northern foothills. Details of the localities and habitats explored are given below. In the list of recorded spiders, each name is followed by a number 
(in parentheses) corresponding to the locality and by a letter corresponding to the habitat from which it was collected. The species recorded from the Tigirek Reserve for the first time are marked with an asterisk (*), while those that are new to the Altai Mts with two asterisks $(* *)$. Digital photographs were taken in a dish with a paraffin-covered bottom. Specimens were photographed using an AxioCam MRc5 (Zeiss) camera attached to a Stemi $2000-\mathrm{C}$ stereomicroscope in the Institute of Systematics and Ecology of Animals, Novosibirsk, Russia (ISEA). Digital images were prepared using Helicon Focus 3.10 image stacking software. Epigyne was macerated in $\mathrm{KOH}$-water solution. All measurements are given in millimeters. While describing the leg spination, apical spines on metatarsi III and IV were not counted. The terminology follows Szinetar et al. [2009]. Spiders from the families Clubionidae and Corinnidae have been deposited in the collection of Zoological Museum of the Moscow State University, Russia (curator: K.G. Mikhailov). The rest of the material has been placed to the collection of the Institute of Systematic and Ecology of Animals, Novosibirsk, Russia (ISEA; curator: G.N. Azarkina).

Abbreviations used in the text are as follows: Leg segments: Fm — femur, $\mathrm{Pa}$ - patella, $\mathrm{Ti}$ — tibia, Mt metatarsus, Ta - tarsus. Leg spination: d - dorsal, p prolateral, $\mathrm{r}$ - retrolateral, $\mathrm{v}$ - ventral. Collectors: AF A.A. Fomichev, AV - A.V. Volynkin, YD - Yu.V. Dyachkov. Locality: TNR — Tigirek State Natural Reserve, Vil. - village.

List of collecting localities:

1) Vicinity of Tigirek Vil. $\left(51^{\circ} 08^{\prime} \mathrm{N}, 83^{\circ} 01^{\prime} \mathrm{E}\right), 500 \mathrm{~m}$ a.s.1., 7.2010, AV.

2) c. $3 \mathrm{~km} \mathrm{NW}$ of Tigirek Vil., Mayak Mt. $\left(51^{\circ} 10^{\prime} \mathrm{N}\right.$, $\left.83^{\circ} 00^{\prime} \mathrm{E}\right), 700-750 \mathrm{~m}$ a.s.1., 26.07.2014, AF.

3) c. $4 \mathrm{~km} \mathrm{~W}$ of Tigirek Vil., Bol'shoi Tigirek River Valley $\left(51^{\circ} 08^{\prime} \mathrm{N}, 82^{\circ} 58^{\prime} \mathrm{E}\right), 500 \mathrm{~m}$ a.s.1., 6.08.2014, AF \& AV.

4) c. $3 \mathrm{~km}$ NWN of Tigirek Vil., Strashnoi Log Gorge $\left(51^{\circ} 10^{\prime} \mathrm{N}, 83^{\circ} 00^{\prime} \mathrm{E}\right), 600-700 \mathrm{~m}$ a.s.1., 26.07.2014, AF.

5) Tigirek Mt. Range, Razrabotnaya Mt. $\left(51^{\circ} 01^{\prime} \mathrm{N}\right.$, $\left.83^{\circ} 01^{\prime} \mathrm{E}\right), 1800-1960 \mathrm{~m}$ a.s.1., 31.07.2014, AF.

6) Tigirek Mt. Range, watershed of Malyi Tigirek and Irkutka Rivers $\left(51^{\circ} 02^{\prime} \mathrm{N}, 83^{\circ} 01^{\prime} \mathrm{E}\right), 1650-1800 \mathrm{~m}$ a.s.1., 31.07.2014, AF.

7) Tigirek Mt. Range, the upper reaches of Bol'shoi Tigirek River, $\left(51^{\circ} 02^{\prime} \mathrm{N}, 83^{\circ} 00^{\prime} \mathrm{E}\right), 1500-1700 \mathrm{~m}$ a.s.l., 30.07 ; 3.08.2014, AF.

8) The same locality (=7), 07.2012, AV

9) Tigirek Mt. Range, watershed of Bol'shoi Tigirek and Babii Klyuch Rivers $\left(51^{\circ} 02^{\prime} \mathrm{N}, 82^{\circ} 59^{\prime} \mathrm{E}\right), 1537 \mathrm{~m}$, 24.08.2014, YD

10) Tigirek Mt. Range, the upper reaches of Babii Klyuch River $\left(51^{\circ} 02^{\prime} \mathrm{N}, 82^{\circ} 57^{\prime} \mathrm{E}\right), 1400-1500 \mathrm{~m}$ a.s.l., 28.07 ; 1-3.08.2014, AF.

11) The same locality (=10), 14-26.08.2014, YD.

12) Tigirek Mt. Range, watershed of Krachalicha and Irkutka Rivers $\left(51^{\circ} 01^{\prime} \mathrm{N}, 82^{\circ} 56^{\prime} \mathrm{E}\right), 1300-1450 \mathrm{~m}$ a.s.1., 2.08.2014, AF

13) Tigirek Mt. Range, watershed of Krachalicha and Babii Klyuch Rivers $\left(51^{\circ} 02^{\prime} \mathrm{N}, 82^{\circ} 57^{\prime} \mathrm{E}\right), 1500 \mathrm{~m}$ a.s.l., 2.08.2014, AF.
Habitats:

A) Meadow near river.

B) Stony steppe meadow with rocks.

C) Subalpine meadow.

D) Stony alpine meadow with rocks.

E) Sphagnum bog.

F) Pinus sibirica - Abies sibirica forest.

G) Moss-lichen mountain tundra.

H) Kurum (stone stream or scree).

\section{Description of new species}

\section{Parasyrisca volynkini sp.n.}

Figs 5-9, 13-14.

TYPE. Holotype $O^{7}$ (ISEA, 001.6269), RUSSIA, Altai Province, Tigirek Mt. Range, Razrabotnaya Mt. $\left(51^{\circ} 01^{\prime} \mathrm{N}, 83^{\circ} 01^{\prime} \mathrm{E}\right)$, kurum, 1800-1960 m a.s.1., 31.07.2014, AF.

COMPARATIVE MATERIAL. Parasyrisca bucklei Marusik et Fomichev, 2010: RUSSIA: $1 \sigma^{T}$ (ISEA, 001.6270), Altai Republic, Ulagan Distr., Kuraiskyi Mt. Range, 10-12 km ENE of Aktash Vil., the upper reaches of Yarlyamry River $\left(50^{\circ} 20^{\prime} \mathrm{N}, 87^{\circ} 44^{\prime} \mathrm{E}\right)$, mountain stony tundra (goltsy), 2500-3000 m a.s.1., 4.07.2010, AF; 2 O $^{\top} \sigma^{7}$ (ISEA, 001.6271), Altai Republic, Kosh-Agach District, Kuraiskyi Mt. Range, near Tydtuyaryk Mt. $\left(50^{\circ} 08^{\prime} \mathrm{N}, 88^{\circ} 27^{\prime} \mathrm{E}\right)$, mountain stony tundra, 3100-3300 m a.s.l., 12.07.2013, AF.

Parasyrisca logunovi Ovtsharenko, Platnick et Marusik, 1995: RUSSIA: holotype $\sigma^{7}$ (ISEA, 000.108), Tuva Republic, MongunTaiga Distr., 30-35 km SE of Mugur-Aksy Vil., Mongun-Taiga Mt., 23.07.1993, 3100-3300 m a.s.1., mountain tundra, D.V. Logunov.

ETYMOLOGY. The specific name is a patronym taken in honour of the well-known Russian entomologist Anton V. Volynkin (Barnaul), a research fellow of the Tigirek Nature Reserve.

DIAGNOSIS. The new species is closely related to two south-Siberian mountain species: P. logunovi and $P$. bucklei, from which it can be distinguished by the shape of conductor $(\mathrm{Cn})$ and its more distal position (Figs 5-6, 8, 11-13). Besides, the new species can be distinguished from $P$. logunovi by the much longer tibial apophysis (Figs 7, 15). The new species differs from both species by a smaller size of the carapace and palp (Table 1) and by the less protruding chelicerae (Figs 9-10).

Table 1. Size differences between the males of three Parasyrisca species.

\begin{tabular}{|l|c|c|c|}
\hline & P. bucklei & P. logunovi & $\begin{array}{c}\text { P. volynkini } \\
\text { sp.n. }\end{array}$ \\
\hline Total length & $9.2-11.5$ & 11.0 & 7.5 \\
\hline Carapace length & $3.8-5.3$ & 4.5 & 3.35 \\
\hline Carapace width & $3.2-4.1$ & 3.9 & 2.7 \\
\hline Cymbium length & $1.7-1.95$ & 1.8 & 1.45 \\
\hline
\end{tabular}

DESCRIPTION. Male. Total length 7.5. Carapace: 3.35 long, 2.7 wide. Coloration. Prosoma and chelicerae brown. Legs and palps light brown. Cymbium dark brown. Opisthosoma grey. Palpal structure as in Figs 5-8, 13-14. Retrolateral tibial apophysis flat, with elongated apical part, reaches more than $1 / 2$ of the tibial length. Conductor straight, widened and flattened apically. Embolus $(E m)$ short and narrow, sharply pointed. Terminal apophysis $(\mathrm{Ta})$ twice as long as embolus. 
Leg measurements:

\begin{tabular}{|l|c|c|c|c|c|c|}
\hline & $\mathrm{Fm}$ & $\mathrm{Pa}$ & $\mathrm{Ti}$ & $\mathrm{Mt}$ & $\mathrm{Ta}$ & Total \\
\hline I & 3.15 & 1.7 & 3.1 & 2.5 & 1.6 & 12.05 \\
\hline II & 2.8 & 1.5 & 2.5 & 1.9 & 1.35 & 10.05 \\
\hline III & 2.55 & 1.3 & 2.1 & 1.7 & 1.2 & 8.85 \\
\hline IV & 3.15 & 1.45 & 2.9 & 2.5 & 1.4 & 11.4 \\
\hline
\end{tabular}

Leg spination:

\begin{tabular}{|l|l|l|l|}
\hline & Fm & $\mathrm{Ti}$ & $\mathrm{Mt}$ \\
\hline $\mathrm{I}$ & $\mathrm{d} 1-1-0 \mathrm{p} 0-0-1$ & $\mathrm{v} 2-2-0$ & $\mathrm{v} 2-0-0$ \\
\hline $\mathrm{II}$ & $\mathrm{d} 1-1-0 \mathrm{p} 0-0-1$ & $\mathrm{v} 2-2-0$ & $\mathrm{v} 2-0-0$ \\
\hline \multirow{2}{*}{$\mathrm{III}$} & $\mathrm{d} 1-1-0 \mathrm{p} 0-1-1$ & $\mathrm{p} 1-1-1 \mathrm{r} 1-0-1$ & $\mathrm{~d} 2-0-0 \mathrm{p} 0-1-0$ \\
& $\mathrm{r} 0-0-1$ & $\mathrm{v} 1-2-2$ & $\mathrm{r} 1-0-0 \mathrm{v} 2-0-0$ \\
\hline \multirow{2}{*}{ IV } & $\mathrm{d} 1-1-0 \mathrm{p} 0-0-1$ & $\mathrm{p} 1-1-1 \mathrm{r} 1-1-1$ & $\mathrm{~d} 2-0-0 \mathrm{p} 0-1-0$ \\
& $\mathrm{r} 0-0-1$ & $\mathrm{v} 2-2-2$ & $\mathrm{r} 0-1-0 \mathrm{v} 1-1-0$ \\
\hline
\end{tabular}

Female unknown.

DISTRIBUTION. The type locality only.

BIOLOGYCAL NOTES. The new species occurs in kurums (stone streams or screes) at the altitudes about $2000 \mathrm{~m}$ a.s.l. In the Tigirek Mt. Range, this habitat is characterized by a high level of the humidity. Contrary to this, the closely related species $P$. bucklei occurs in the dry and much colder stony mountain tundras and alpine meadows of the south-east Altai at the altitudes between 2400 to $3300 \mathrm{~m}$ a.s.l. [Marusik, Fomichev, 2010; Fomichev, unpublished data].

\section{List of species}

AGELENIDAE (1)

Agelena labyrinthica (Clerck, 1757): 3 우 [1].

AMAUROBIIDAE (1)

Arctobius agelenoides (Emerton, 1919): 1 9 [7d], 2

우 [8], $1 \sigma^{\top}[9 \mathrm{~g}]$.

ARANEIDAE (7)

Aculepeira carbonarioides (Keyserling, 1892): 1 ㅇ

[6h], 1 ○ 2 우 [8], 1 + [10h], $1 \bigcirc^{7}$ [12h].

Aculepeira ceropegia (Walckenaer, 1802): $1+[2 \mathrm{~b}]$,

1 + $[12 \mathrm{c}]$.

*Araneus diadematus Clerck, 1757: 1 ㅇ [1], 1 O 2 १o [7cf].

COMMENTS. The species is widely distributed in the Holarctic Region [WSC, 2015]; first record for the TNR.

Araneus quadratus Clerck, 1757: 1 [2b].

Araniella displicata (Hentz, 1847): $1 \bigcirc^{7}$ [7c], 1 \% [8].

Larinioides patagiatus (Clerck, 1757): 1 ठ [10c].

Mangora acalypha (Walckenaer, 1802): 2 우 [1].

CLUBIONIDAE (4)

*Clubiona caerulescens L. Koch, 1867: 1 + [1].

COMMENTS. Species has a trans-Palaearctic boreo-nemoral range [Marusik et al., 2000]; first record for the TNR.

Clubiona germanica Thorell, 1871: $1 \bigcirc^{7}$ [1].

Clubiona lutescens Westring, 1851: 1 [1].

*Clubiona pseudosaxatilis Mikhailov, 1992: $1 \sigma^{7} 3$

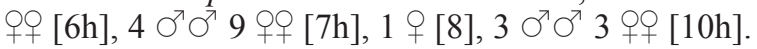

COMMENTS. Species is known from East-Kazakhstan to Tuva [Mikhailov, 1992]; first record for the TNR.

CORINNIDAE (1)

Phrurolithus festivus (C.L. Koch, 1835): $1+$ [12c].

DICTYNIDAE (2)

*Dictyna arundinacea (Linnaeus, 1758): $1+$ [1].

COMMENTS. This species has a circum-Holarctic polyzonal range [Marusik et al., 1996]; first record for the TNR.

*Lathys alberta Gertsch, 1946: 5 + [7d].

COMMENTS. The species has a Siberian - West Nearctic range [Marusik, Eskov, 2009]; first record for the TNR.

\section{ERESIDAE (1)}

Eresus kollari Rossi, 1846: $2 \sigma^{7} \sigma^{7}[1]$.

COMMENTS. This species was previously reported from the TNR as E. cinnaberinus (Olivier, 1789) [Balasheva, 2006; Trilikauskas, pers. comm.]. The species has a trans-Palaearctic nemoral range [Marusik et al., 2000].

GNAPHOSIDAE (8)

Drassodes cupreus (Blackwall, 1834): $1+$ [7d], 19 [8], 8 우 [10h], 2 ㅇ [12ch], 1 \% [13d].

*Drassodes villosus (Thorell, 1856): 1 + [2b].

COMMENTS. This species has a trans-Palaerctic boreo-nemoral range [Marusik et al., 2000]; first record for the TNR.

*Gnaphosa inconspecta Simon, 1878: 1 \% [8].

COMMENTS. Species has a trans-Palaearctic boreo-montane disjunctive range [Marusik et al., 2000]; first record for the TNR.

*Micaria alpina L. Koch, 1872: $2 \sigma^{7} \sigma^{7} 1 \%$ [8].

COMMENTS. The species has a sub-circum-Holarctic boreo-hypoarctic range [Marusik et al., 2000]; first record for the TNR.

Micaria nivosa L. Koch, 1866: 2 우 [1].

Parasyrisca volynkini sp.n. (see above): $1 \bigcirc^{7}[5 \mathrm{~h}]$; Figs 5-9, 13-14. [13d].

Parasyrisca sp.: 1 ○ 2 우 [7d], 1 + [8], $1 \sigma^{\top} 1$ ㅇ

COMMENTS. Probably, these specimens belong to an undescribed species which is very closely related to $P$. logunovi, but differs in the conformation of its receptacles.

Zelotes fratris Chamberlin, 1920: $1 \sigma^{\top} 1+[10 \mathrm{~h}]$.

\section{LINYPHIIDAE (8)}

*Leptorhoptrum robustum (Westring, 1851): 1 [10c]; Figs 1-4.

COMMENTS. This species has a trans-Palaearctic - West Nearctic boreo-nemoral range [Marusik et al., 2000]; first record for the TNR. Despite the existence of a large number of papers dealing with this species [WSC, 2015], the female of this unusually-looking linyphiid is still difficult to identify due to the lack of 

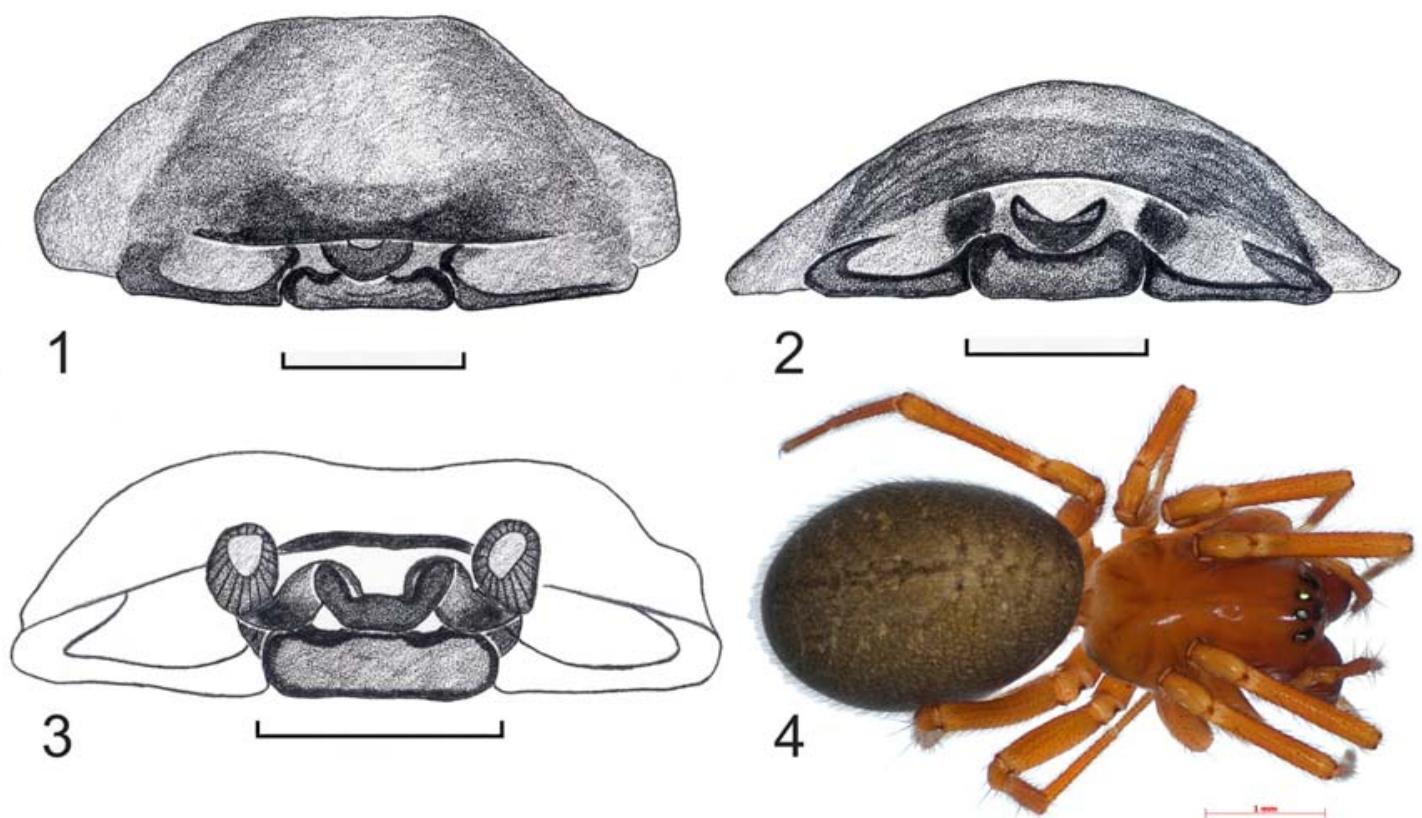

Figs 1-4. Epigyne (1-3) and female habitus (4) of Leptorhoptrum robustum. 1 - ventral view; 2 - posterior view; 3-4 - dorsal view. Scale bars: $1-3-0.2 \mathrm{~mm} ; 4-1 \mathrm{~mm}$.

Рис. 1-4. Эпигина (1-3) и внешний вид самки (4) Leptorhoptrum robustum. 1 - вид вентрально; 2 - вид сзади; 3-4 - вид дорсально. Масштабные линейки: $1-3-0,2$ мм; $4-1$ мм.

proper illustrations. This is why we have provided new figures thereof (Figs 1-4).

Neriene emphana (Walckenaer, 1841): $1 \bigcirc^{7}$ [12c].

**Obscuriphantes obscurus (Blackwall, 1841): 1 $\sigma^{7}[10 \mathrm{~h}]$.

COMMENTS. The species is known from Europe to Western Siberia [Mikhailov, 2013]; first record from the TNR and the Russian Altai.

*Scotinotylus protervus (L. Koch, 1879): $3 \sigma^{7} \sigma^{7} 17$ 우 [5h], 1 [7d], 7 우 [7h], $1 \bigcirc^{7} 13$ ㅇ [10h].

COMMENTS. This species has a Siberio - NW Nearctic hypoarcto-montane range [Marusik et al., 2000]; first record for the TNR.

Stemonyphantes taiganoides Tanasevitch, Esyunin et Stepina, 2012: $1 O^{7}$ [11c].

**Tibioploides arcuatus (Tullgren, 1955): 3 ++ [9g].

COMMENTS. The species has a trans-Palaearctic boreal range; first record for the TNR and the Russian Altai.

**Walckenaeria karpinskii (O.Pickard-Cambridge, 1873): 1 \& [7h].

COMMENTS. This species has a Circum-Holarctic arcto-boreo-montane range [Marusik et al., 2000]; first record for the TNR and the Russian Altai.

** Walckenaeria kazakhstanica Eskov, 1995: 1 \% [4b].

COMMENTS. The species distributed from the south Urals [Esyunin, Efimik, 1996] through East Kazakhstan Region [Eskov, Marusik, 1995] to Tuva [Marusik et al., 2000]; first record for the TNR and the Russian Altai.

\section{LYCOSIDAE (10)}

Acantholycosa altaiensis Marusik, Azarkina et Koponen, 2004: $1 \sigma^{\top} 1+$ [6h], $1 \sigma^{7} 1+[10 \mathrm{~h}]$.

* Pardosa amentata (Clerck, 1757): 1 [ [1].

COMMENTS. Distributed from Western Europe to

Tuva [Marusik et al., 2000]; first record for the TNR.

Pardosa bifasciata (C.L. Koch, 1834): $1+$ [1].

Pardosa lugubris (Walckenaer, 1802): 5 of [1].

Pardosa oksalai Marusik, Hippa et Koponen, 1996: 2 우 [11c].

*Pirata piraticus (Clerck, 1757): $1 \bigcirc^{7}$ [10e].

COMMENTS. The species is widely distributed in the Holarctic Region [WSC, 2015]; first record for the TNR.

Piratula hygrophila (Thorell, 1872): 6 ㅇ [1].

Trochosa spinipalpis (F.O. Pickard-Cambridge, 1895): 1 ठ $^{7}[10 \mathrm{e}]$.

Xerolycosa nemoralis (Westring, 1861): 2 q० [1].

OXYOPIDAE (1)

Oxyopes ramosus (Martini et Goeze, 1778): $1+[1]$.

PHILODROMIDAE (4)

Artanes marusiki Logunov, 1997: $1 \sigma^{\top}$ [1].

Philodromus cespitum (Walckenaer, 1802): 1 9 [1], 2 우 [2b].

*Thanatus arcticus Thorell, 1872: $1 \sigma^{7}$ [8].

COMMENTS. This species has a circum-Holarctic polyzonal range [Marusik et al., 2000]; first record for the TNR.

Tibellus oblongus (Walckenaer, 1802): 1 ○ 2 우 [1], $1+[2 \mathrm{~b}]$. 

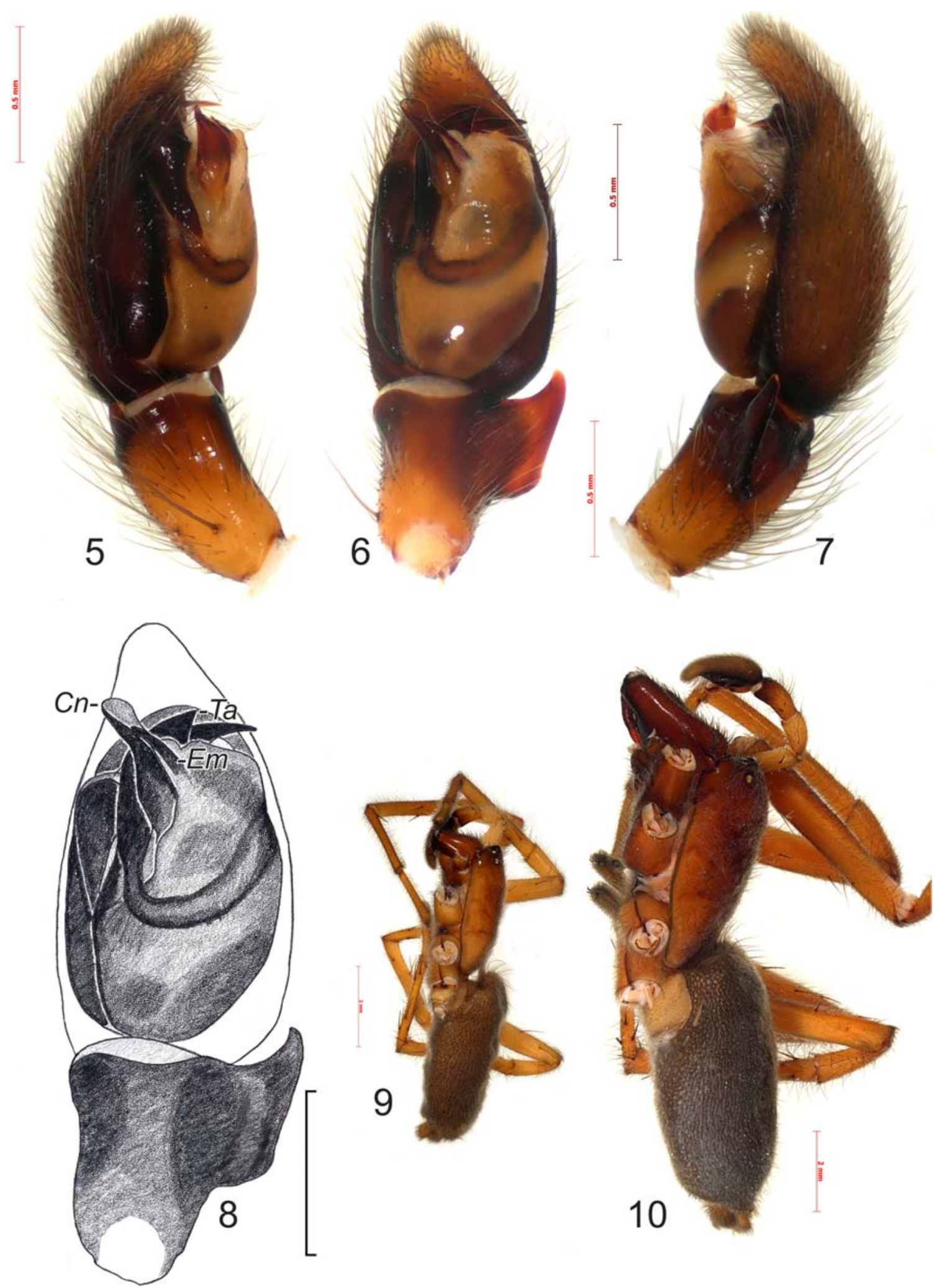

Figs 5-10. Male palp (5-8) and habitus (9) of Parasyrisca volynkini sp.n. and male habitus of P. bucklei (10). 5 - prolateral view; 6 , 8 - ventral view; 7 - retrolateral view; $9-10-$ lateral view. Scale bars: $5-8-0.5 \mathrm{~mm}$; $9-10-2 \mathrm{~mm}$. Abbreviations: $\mathrm{Cn}-$ conductor, Em - embolus, $T a$ - terminal apophysis.

Рис. 5-10. Пальпа (5-8) и внешний вид (9) самца Parasyrisca volynkini sp.n. и внешний вид самца P. bucklei (10). 5 - вид пролатерально; 6, 8 - вид вентрально; 7 - вид ретролатерально; 9-10 - вид сбоку. Масштабные линейки: 5-8 - 0,5 мм; 9-10 2 мм. Сокращения: $C n-$ кондуктор, $E m$ - эмболюс, $T a$ - терминальный отросток. 

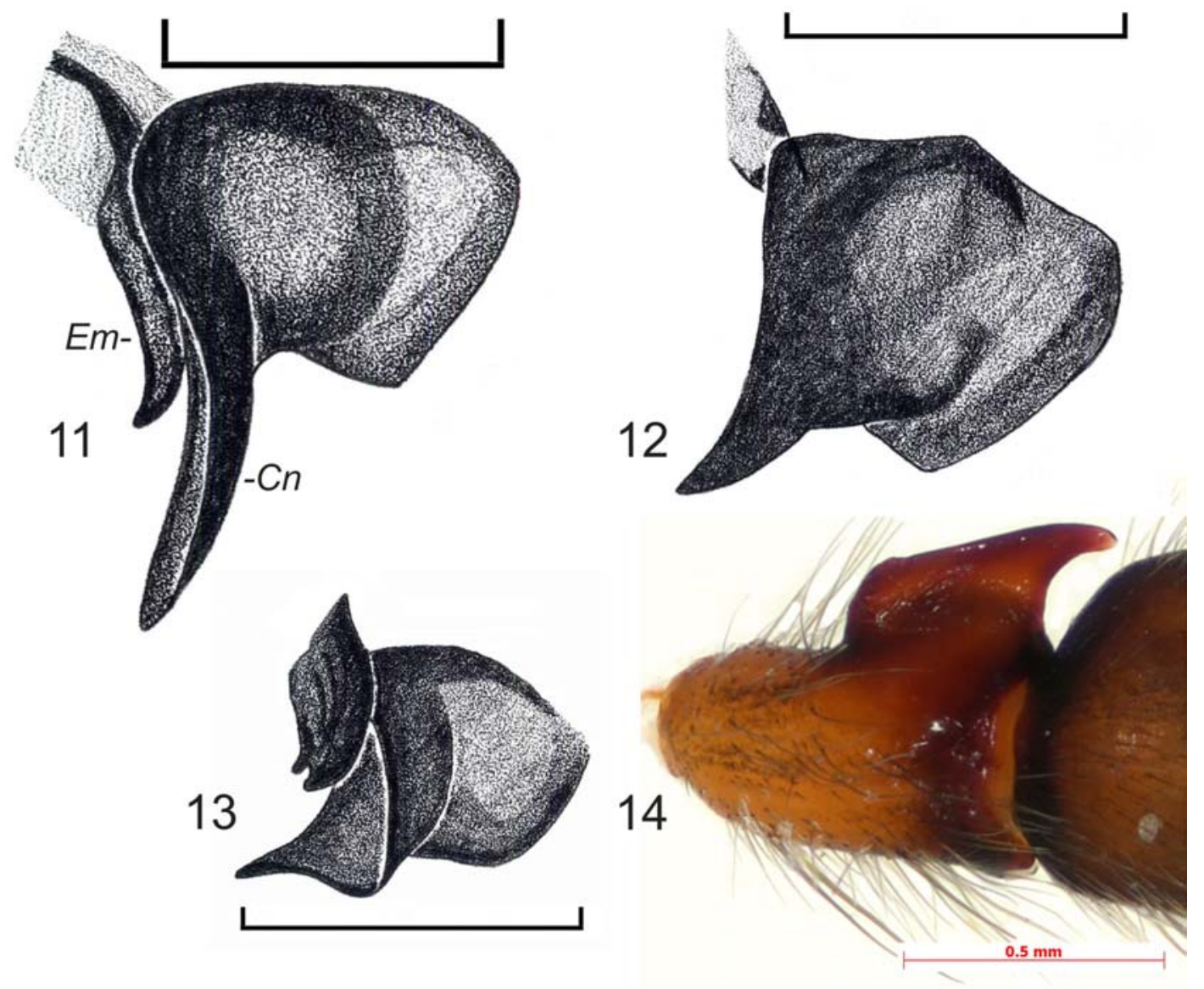

Figs 11-14. Conductor and embolus (11-13) of Parasyrisca buckei (11), P. logunovi, the holotype from Tuva (12) and P. volynkini sp.n. (13); male palpal tibia of $P$. volynkini sp.n. (14). 11-13 - apical view; 14 - dorsal view. Scale bars: $11-13-0.2 \mathrm{~mm} ; 14-0.5$ $\mathrm{mm}$. Abbreviations: $\mathrm{Cn}$ - conductor, $\mathrm{Em}$ - embolus.

Рис. 11-14. Кондуктор и эмболюс (11-13) Parasyrisca buckei (11), P. logunovi, голотип из Тувы (12) и P. volynkini sp.n. (13); голень пальпы самца $P$. volynkini sp.n. (14). 11-13 — вид апикально; 14 - вид дорсально. Масштабные линейки: 11-13 - 0,2 мм; $14-0,5$ мм. Сокращения: $\mathrm{Cn}$ - кондуктор, $E m-$ эмболюс.

PISAURIDAE (1)

Pisaura mirabilis (Clerck, 1757): 1 [2b].

SALTICIDAE (5)

Evarcha arcuata (Clerck, 1757): 3 ○ $^{7}$ [2b], $1 \bigcirc^{7}$ [3a]. Evarcha falcata (Clerck, 1757): $1 \sigma^{7}$ [1].

Heliophanus flavipes (Hahn, 1832): 1 일.

**Sibianor tantulus (Simon, 1868): $1 \sigma^{7}$ [3a].

COMMENTS. The species has a trans-Palaearctic temperate range [Logunov, 2001]; first record for the TNR and the Russian Altai.

Sitticus floricola (C.L. Koch, 1837): 4 +P [10ch].

SPARASSIDAE (1)

Micrommata virescens (Clerck, 1757): 1 + [2b].

THERIDIIDAE (4)

**Euryopis laeta (Westring, 1861): 1 ๆ [1]; Figs $16-18$.

COMMENTS. The species is known from Europe to East Kazakhstan [Savelyeva, 1979; Mikhailov, 2013]; first record for the TNR and the Russian Altai. The new record represents the easternmost locality of the species range. Epigyne and female habitus are shown in Figs 16-18.

*Lasaeola tristis (Hahn, 1833): 1 [1].

COMMENTS. This species has a European-West Siberian range [Marusik et al., 1996]; first record for the TNR. [2b].

Phylloneta impressa (L. Koch, 1881): 1 [1], 2 우

Steatoda albomaculata (De Geer, 1778): 5 우 [1].

THOMISIDAE (8)

Lysiteles maior Ono, 1979: $6 \sigma^{7} \sigma^{7}$ [7c], $1 \sigma^{7}$ [8].

COMMENTS. This species has a peculiar range. It is recorded from the Altai, West Sayany Mts and western Buryatia, and then, after a disjunction in AmurMaritime Area, Sakhalin, Kunashir and Honshu Islands (Japan) in the east, and southward to Nepal [Ono et al., 1990; Danilov, 1993; Logunov, Marusik, 1994; Marusik et al., 2000; Marusik, 2009; Volynkin et al., 2011]. 

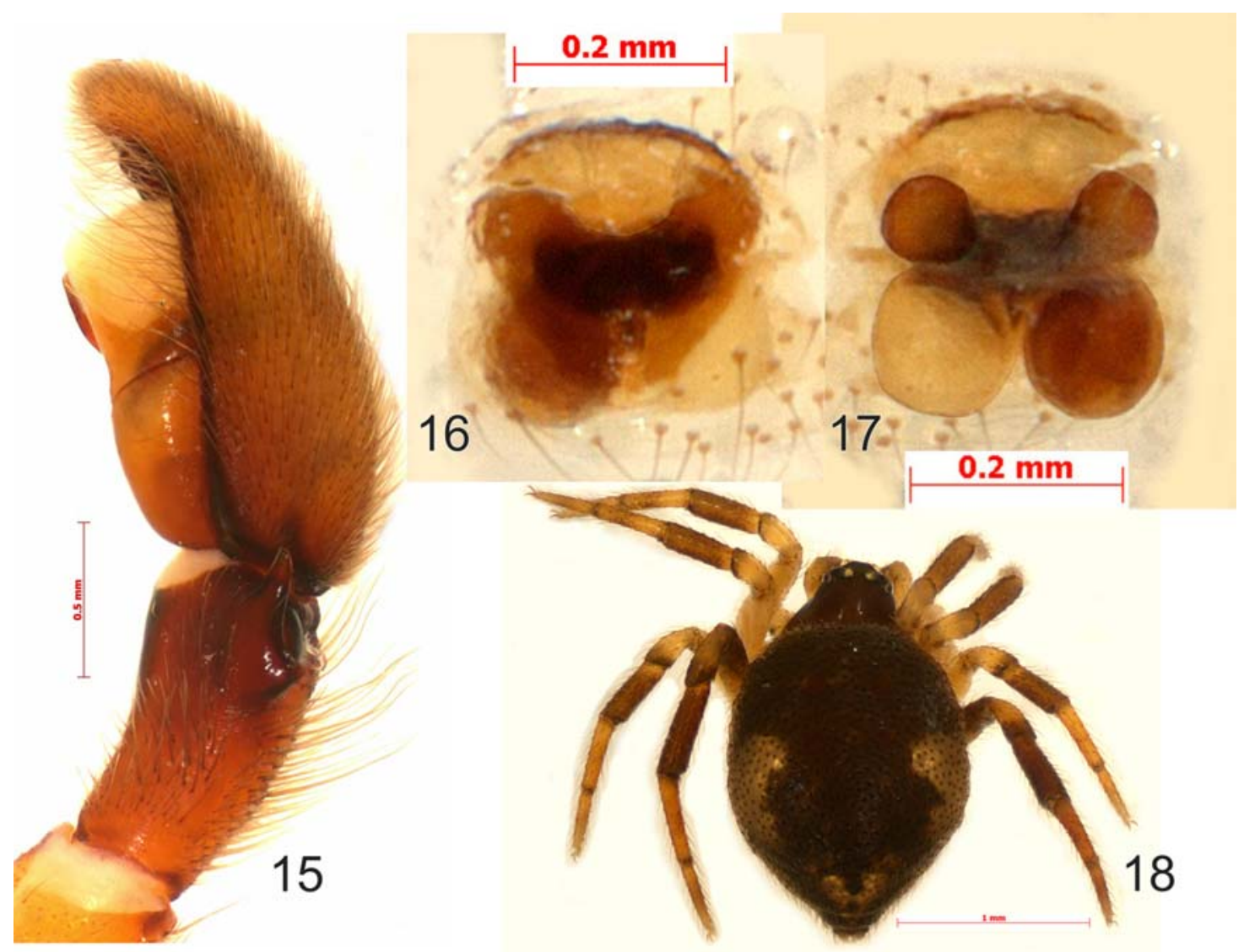

Figs 15-18. Male palp of P. logunovi (15) and epigyne (16-17) and female habitus (18) of Euryopis laeta. 15 - retrolateral view; 16 - ventral view; 17 - dorsal view; $18-$ posterior view. Scale bars: $15-0.5 \mathrm{~mm} ; 16-17-0.2 \mathrm{~mm} ; 18-1 \mathrm{~mm}$.

Рис. 15-18. Пальпа самца $P$. logunovi (15) и эпигина (16-17) и внешний вид самки (18) Euryopis laeta. 15 - ретролатерально; 16 - вентрально; 17 - дорсально; 18 - сзади. Масштабные линейки: $15-0.5$ мм; 16-17-0,2 мм; $18-1$ мм.

Misumena vatia (Clerck, 1757): 2 ㅇ [2b]. Tmarus piger (Walckenaer, 1802): 2 o+ [1].

*Xysticus austrosibiricus Logunov et Marusik, 1998: 1 O $^{\text {T }}$ [8].

COMMENTS. The species is widespread in the mountains of South Siberia and Mongolia [Logunov, Marusik, 1998]. It was also been recorded from China [Liu et al., 2015]. First record for the TNR.

Xysticus bonneti Denis, 1938: 2 ○ $^{7} 12$ 우 [7dh], $5 \bigcirc^{7} \sigma^{7} 28$ ㅇ [8], 1 + [13d].

* Xysticus obscurus Collett, 1877: 1 + [8].

COMMENTS. It has a circum-Holarctic boreo-alpine range [Marusik et al., 2000]; first record for the TNR.

Xysticus robustus (Hahn, 1832): 1 [ [1].

Xysticus ulmi (Hahn, 1831): 1 + [1].

\section{Discussion}

To sum up, the spider fauna of the Tigirek Nature Reserve has been complemented by 23 additional species and now numbers 176 species of 97 genera and 22 families. Among all spider families recorded from the reserve, Linyphiidae (32 species, 18.2\%) and Lycosidae (29 species, 16.5\%) predominate. A significant number of species have been recorded from the families Gnaphosidae, Thomisidae and Araneidae (22 species, $12.5 \%$; 20 species, $11.4 \%$; 17 species, $9.7 \%$; respectively). The remaining families are presented by a small number of species. The spider fauna of the Tigirek Nature Reserve is mainly composed by widespread species, with (trans)Palaearctic, (circum)Holarctic, and Euro-Siberian/Mongolian species predominating. Endemics of the Altai-Sayan Mt. Region, which are usually confined to the subalpine meadows and kurums, account for 10 species or $5.7 \%$ of the entire spider fauna. There is no doubt that the spider fauna of the Tigirek Nature Reserve still remains documented incompletely. As shown by Marusik \& Koponen [2002], the wolf-spiders (Lycosidae) can be used as a good indicator of the species diversity in local Siberian faunas. The percentage of Lycosidae species in local faunas of the temperate regions of Eurasia varies in a small range, from 7 to $12 \%$ [Marusik, Koponen, 2002]. 
Therefore, it is safe to conclude that a predictable spider diversity of the Tigirek Nature Reserve should be at least 240 species or more.

ACKNOWLEDGEMENTS. I wish to thank the director of the Tigirek Nature Reserve, P.V. Golyakov and his employees, T.M. Krugova and A.V. Volynkin (all from Barnaul, Russia) for their help in the organization of field trips to the reserve in which the material studied here was collected. Thanks go to A.V. Volynkin and Yu.V. Dyachkov (both from Barnaul, Russia) for their great help in collecting. I am grateful to A.V. Tanasevitch (Moscow, Russia) and Yu.M. Marusik (Magadan, Russia) for their help in the identification of some Linyphiidae. K.G. Mikhailov (Moscow, Russia) is thanked for providing me with information about the current distribution of Euryopis laeta and Lasaeola tristis. I also thank R.Yu. Dudko (ISEA) for providing me with the ISEA facilities and G.N. Azarkina (ISEA) for giving access to the comparative material from the ISEA. The earlier draft of the manuscript was reviewed by D.V. Logunov (Manchester, UK), Yu.M. Marusik and L.A. Trilikauskas (ISEA). The English of the final draft was kindly edited by D.V. Logunov.

\section{References}

Azarkina G.N., Logunov D.V. 2000. Separation and distribution of Xysticus cristatus (Clerck, 1758) and X. audax (Schrank, 1803) in eastern Eurasia, with description of a new species from the mountains of Central Asia (Aranei: Thomisidae) // Arthropoda Selecta. Vol.9. No.2. P.133-150.

Azarkina G.N., Trilikauskas L.A. 2012. New data on spider fauna (Aranei) of the Russian Altai, part I: families Agelenidae, Araneidae, Clubionidae, Corinnidae, Dictynidae and Eresidae // Eurasian entomol. J. Vol.11. No.3. P.199-208. P1.I.

Azarkina G.N., Trilikauskas L.A. 2013a. New data on spider fauna (Aranei) of the Russian Altai, part II: families Gnaphosidae, Hahniidae, Linyphiidae, Liocranidae and Lycosidae // Euroasian entomol. J. Vol.12. No.1. P.51-67.

Azarkina G.N., Trilikauskas L.A. 2013b. New data on spider fauna (Aranei) of the Russian Altai, part III: families Mimetidae, Miturgidae, Oxyopidae, Philodromidae, Pholcidae, Pisauridae, Salticidae, Sparassidae, Tetragnathidae, Theridiidae, Thomisidae, Titanoecidae, Uloboridae and Zoridae // Euroasian entomol. J. Vol.12. No.3. P.243-254.

Balasheva V.A. 2006. [Eresus cinnaberinus (Oliver, 1787)] // Krasnaya Kniga Altaiskogo Kraya. Redkie i nakhodyashchiesya pod ugrozoi ischeznoveniya vidy zhivotnych. Barnaul. Vol.2. P.29-29 [in Russian].

Danilov S.N. 1993. Crab spiders (Aranei Thomisidae, Philodromidae) of Transbaikalia. 1. // Arthropoda Selecta. Vol.2. No.1. P.61-67.

Davydov E.A., Botchkareva E.N., Chernykh D.V. 2011. [Natural conditions of the Tigirek Strict Nature Reserve] // Trudy Tigirekskogo Zapovednika. Barnaul. Vol.4. P.7-19 [in Russian].

Efimik V.E., Esyunin S.L. 1996. A new subgenus and a new species of Walckenaeria Blackwall, 1833, from the Urals with remarks on the distribution of some unicornis-group species in the Palearctic (Aranei Linyphiidae) // Arthropoda Selecta. Vol.5. No.1/2. P.63-73.

Eskov K.Yu., Marusik Yu.M. 1995. On the spiders from Saur Mt. range, eastern Kazakhstan (Arachnida: Araneae) // Beitr. Araneol. Bd.4. P.55-94.

Liu L., Guo C.H., Zhang F. 2015. Two newly recorded species of the genus Xysticus (Araneae: Thomisidae) from China // J. Hebei Univ., Nat. Sci. Edi. Vol.35. No.1. P.58-61.

Logunov D.V. 2001. A redefinition of the genera Bianor Peckham \& Peckham a.s.l., 1885 and Harmochirus Simon, 1885, with the establishment of a new genus Sibianor gen. n. (Aranei: Salticidae) // Arthropoda Selecta. Vol.9. No.4. P.221-286.

Logunov D.V., Marusik Yu.M. 1994. A faunistic review of the crab spiders (Araneae, Thomisidae) from the mountains of
South Siberia // Bull. Inst. Roy. Sci. Natur. Belgique, Entomol. T.64. P.177-197.

Logunov D.V., MarusikYu.M. 1998. A new species of the genus Xysticus from the mountains of South Siberia and Mongolia (Araneae, Thomisidae) // Bull. Br. arachnol. Soc. Vol.11. Part 3. P.103-106.

Logunov D.V., MarusikYu.M. 2000. Miscellaneous notes on Palaearctic Salticidae (Arachnida: Aranei) // Arthropoda Selecta. Vol.8. No.4. P.263-292.

Lukhtanov V.A., Vishnevskaya M.S., Volynkin A.V., Yakovlev R.V. 2007. Butterflies (Lepidoptera, Rhopalocera) of West Altai // Entomological Review. Vol.87. No.5. P.524-544.

Marusik Yu.M. 2009. A check-list of spiders (Aranei) from the Lazo Reserve, Maritime Province, Russia // Arthropoda Selecta. Vol.18. No.1-2. P.95-109.

Marusik Yu.M., Azarkina G.N., Koponen S. 2004. A survey of East Palaearctic Lycosidae (Aranei). II. Genus Acantholycosa Dahl, 1908 and related new genera // Arthropoda Selecta. Vol.12. No.2. P.101-148.

Marusik Yu.M., Eskov K.Yu. 2009. Spiders (Arachnida: Aranei) of the tundra zone of Russia. Golovatch S.I., Makarova O.L., Babenko A.B., Penev L.D. (eds.) // Species and Communities in Extreme Environments (Festschrift towards the $75^{\text {th }}$ Anniversary and a Laudatio in Honour of Academician Yuri Ivanovich Chernov. Sofia-Moscow. P.131-164.

Marusik Yu.M., Fomichev A.A. 2010. A new species of Parasyrisca Schenkel, 1963 (Araneae, Gnaphosidae) from the Altai // Zootaxa. Vol.2626. P.65-68.

Marusik Yu.M., Hippa H., Koponen S. 1996. Spiders from the Altai area, South Siberia // Acta Zoologica Fennica. Vol.201. P.11-45.

Marusik Yu.M., Koponen S. 2002. Diversity of spiders in boreal and arctic zones // J. Arachnology. Vol.30. P.205-210.

Marusik Yu.M., Logunov D.V., Koponen S. 2000. Spiders of Tuva, South Siberia. Magadan: IBPN FEB RAS. 252 pp.

Mikhailov K.G. 1992. The spider genus Clubiona Latreille, 1804 (Arachnida Aranei Clubionidae) in the USSR fauna: a critical review with taxonomical remarks // Arthropoda Selecta. Vol.1. No.3. P.3-34.

Mikhailov K.G. 2013. The spiders (Arachnida: Aranei) of Russia and adjacent countries: a non-annoteted cheklist. Arthropoda Selecta. Supplement No.3. 262 pp.

Ono H., Marusik Yu.M., Logunov D.V. 1990. Spiders of the family Thomisidae from Sakhalin and the Kurile Islands // Acta Arachnologica. Vol.39. No.1. P.7-19.

Savelyeva L.G. 1979. [Zoogeographical complexes of spiders (Aranei) in East Kazakhstan] // Priroda i khozyaistvo Vostochnogo Kazakhstana. Alma-Ata: Nauka Publ. P.139-148 [in Russian].

Szinetar C., Eichardt J., Szüts T. 2009. The first lowland species of the Holarctic alpine ground spider genus Parasyrisca (Araneae, Gnaphosidae) from Hungary // ZooKeys. Vol.16. P.197-208.

Trilikauskas L.A. 2014. [On some seasonal aspects of spiders and harvestmen population (Arachnida: Aranei, Opiliones) in larch forests of the Tigirekski Reserve (North-Western Altai)] // Tomsk State University Journal of Biology. Vol.28. No.4. P.123-135 [in Russian, with English summary].

Volynkin A.V., Trilikauskas L.A., Baghirov R.T-O., Burmistrov M.V., Byvaltsev A.M., Vasilenko S.V., Vishnevskaya M.S., Danilov Yu.N., Dudko A.Yu., Dudko R.Yu., Knyshov A.A., Kosova O.V., Kostrov D.V., Krugova T.M., Kuznetsova R.O., Kuzmenkin D.V., Legalov A.A., Lvovsky A.L., Namyatova A.A., Nedoshivina S.V., Perunov Yu.E., Reschnikov A.V., Sinev S.Yu., Solovarov V.V., Tyumaseva Z.I., Udalov I.A., Ustyuzhanin P.Ya., Filimonov R.V., Tshernyshev S.E., Tshesnokova S.V., Sheikin S.D., Shcherbakov M.V., Yanygina L.V. 2011. [Invertebrates of the Tigirek Nature Reserve (an annotated check-list), Biota of the Tigirek Natural Reserve] // Trudy Tigirekskogo Zapovednika. Barnaul. Vol.4. P.165-226 [in Russian, with English summary].

WSC 2015.World Spider Catalog, Version 16.5. Natural History Museum Bern; online at: http://wsc.nmbe.ch (accessed on August, 2015).

Responsible editor D.V. Logunov 